\title{
Zooplankton biomass to chlorophyll ratios in relation to trophic status within and between ten South African reservoirs: Causal inferences, and implications for biomanipulation
}

\author{
RC Hart* \\ School of Biological and Conservation Sciences, University of KwaZulu-Natal, Private Bag X01, Scottsville 3209 \\ Pietermaritzburg, South Africa
}

\begin{abstract}
Rising eutrophication in South African reservoirs is of major concern, leading to the consideration of top-down biomanipulation as a management option - reducing zooplankton-eating fish to sustain zooplankton grazing pressure and thus restrict autotrophic plankton that proliferate with nutrient increases. The biomass ratio of zooplankton to phytoplankton (ZB/PB) is used as an index of the likely value of biomanipulation to achieve this outcome, but values have not been explored for South African systems. Using chlorophyll (Chl) as a surrogate for PB, available ZB/Chl data are assembled for the first time for ten reservoirs of three types (minerally-turbid systems, oligo/mesotrophic clear water systems, and eutrophic/hypertrophic systems), and the results are discussed in relation to a generalised conceptual model proposed. With the exception of one minerally-turbid system, $\mathrm{ZB} / \mathrm{Chl}$ values decline quasi-exponentially with rising chlorophyll within individual reservoirs. Conversely, between individual systems, median (or mean) values of $\mathrm{ZB} / \mathrm{Chl}$ conversely increase rather than decline with rising trophic status - broadly contradicting observations reported elsewhere. Underlying causal reasons for the observed pattern and its implications for biomanipulation are considered. This assessment evaluates: the negative impacts of general declines in food quality that stem from rising eutrophication on zooplankton feeding ability and resulting seasonal changes in ZB and community structure; prospects of food sources other than living autochthonous autotrophs in sustaining ZB between systems; and inferences about fish predation pressure on zooplankton, derived from empirical data regarding the large body sizes of species and individuals of Daphnia that occur in the reservoirs. Observed increases in median ZB/Chl ratios with rising nutrient status are consistent with the inference that obligate visual zooplanktivorous fishes are scarce or absent, particularly in eutrophic reservoirs, suggesting that biomanipulative management is unlikely to assist in controlling the consequences of nutrient enrichment in local reservoirs.
\end{abstract}

Keywords: Biomanipulation, eutrophication, food webs, food quality, interactions, plankton communities

\section{Introduction}

Cultural eutrophication is a familiar phenomenon known for decades (e.g. OECD, 1982; Schindler, 2006). Smith and Schindler (2009) state that it has become the primary water quality issue in most of the freshwater and coastal marine ecosystems in the world. Its impact is of growing global concern in view of its multiple adverse consequences on the structure and functioning of affected ecosystems (e.g. Holdren, 2001; Jeppesen et al., 2003b; Osborne, 2005; Phillips, 2005; Søndergaard and Jeppesen, 2007). Harmful algal blooms (HABs) with adverse ecosystem implications and potential human health problems commonly emerge (Graham, 2007). Krantzberg et al. (2010) indicate that $20 \%$ of the world's population (more than one billion people) are at risk of water-related diseases associated with water pollution, while pathogens can benefit from the higher nutrient levels in eutrophic waters (Smith and Schindler, 2009). The greater vulnerability of warm and tropical waters to eutrophication problems (Jeppesen et al., 2003b, 2005; Hart, 2006b) is an emerging concern of particular relevance to South Africa, a water-scarce country, largely dependent on water stored in man-made reservoirs (reservoirlakes) for the sustained supply of raw potable and irrigation water.

\footnotetext{
* To whom all correspondence should be addressed.

푱 +27 33 260-5103; fax: +27 33 260-5117; e-mail: hartr@ukzn.ac.za

Received 31 October 2010; accepted in revised form 5 September 2011.
}

South African reservoirs impound at least $50 \%$ of the mean annual runoff in the country (DWAF, 2004). Some $35 \%$ of this stored water is currently classified as eutrophic or hypertrophic - with nutrient levels greatly exceeding generally-accepted trophic boundaries (Harding et al., 2009). Bulk nutrient loading of many inland South African reservoirs derives from wastewater return flows, leading in many cases to cyanobacterial blooms (Van Ginkel et al., 2000, 2006; Harding et al., 2009). Harding (2008) has estimated that nutrient load reductions of between 25 and $96 \%$ will be necessary to attain in situ threshold concentrations amenable to an acceptable reduction in the frequency of cyanobacterial blooms. However, the prospects of such reductions are poor, given the parlous state of increasingly over-loaded wastewater treatment plants in the country (DWA, 2009). Accordingly, alternative in-lake management options attract growing consideration, with food web modification (biomanipulation) emerging as a possible prospect (e.g. Harding et al., 2009).

The basic principles behind the biomanipulation approach to lake restoration are widely known (e.g. Gulati et al., 1990; Moss, 1998a; Hansson et al., 1998), and are not elaborated here. While the approach has been widely applied internationally, its successes are outnumbered by failures, certainly in the longer term (Gulati and Van Donk, 2002; Søndergaard and Jeppesen, 2007; Søndergaard et al., 2007; Gulati et al., 2008). Successful outcomes are more frequent in shallow natural lakes where submerged hydrophytes compete with phytoplankton for nutrients, and also provide a visual refuge 

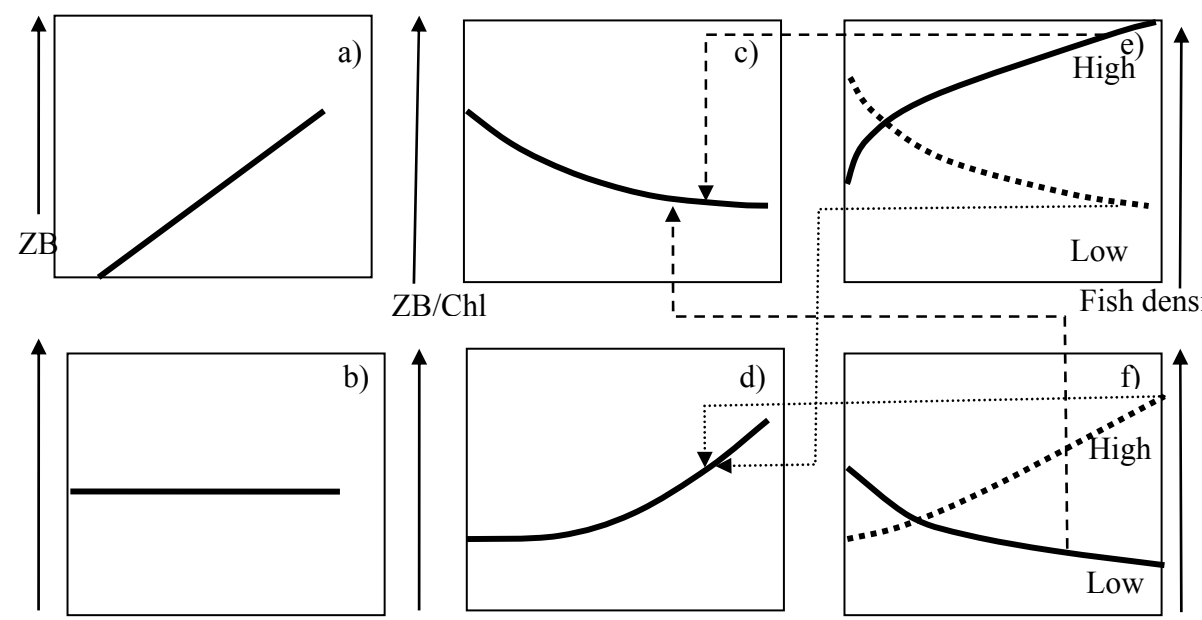

$\mathrm{ZB} / \mathrm{Chl}$ b)

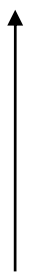

$\mathrm{ZB} / \mathrm{Chl}$

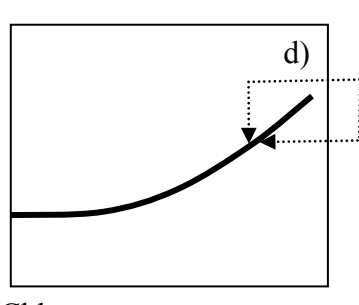

Food Quantity/Trophic status (as chlorophyll)

Figure 1

A general conceptual model showing the responses of different variables to rising chlorophyll as a measure of food supply and a proxy for increasing trophic/nutrient status(the abscissa for all panels): a) zooplankton biomass (ZB), b) zooplankton abundance standardised for food supply (ZB/Chl); $c$ ) and d) alternative responses of $Z B / C h l$ to food supply; e) alternative changes in zooplanktivorous fish abundance and f) alternative changes in food quality, with changing trophic status. Dashed lines show that the common empirical pattern (e.g. Jeppesen et al., 2003a, 2007) of declining ZB/Chl can arise from increased predation by rising densities of fish (e), but can also or alternatively derive from declining food quality (f). Dotted lines reflect how obverse changes in e) and f) could account for a progressive increase in $\mathrm{ZB} / \mathrm{Ch} /$ with rising trophic status. against obligate visually-feeding zooplanktivorous fishes (Jeppesen et al., 1997). Nevertheless, the sustainability of successful food web manipulation has been found wanting on several grounds, even in such natural lakes (Gliwicz 2005; Søndergaard et al., 2007; Gulati et al., 2008). In South African reservoirs, obligate visual zooplanktivores are effectively absent, and most reservoir systems are deep enough to stratify (Allanson et al., 1990), and thus exceed the 'arbitrary' deep/shallow depth threshold, of aprox. $6 \mathrm{~m}$, associated with effective biomanipulation prospects (Jeppesen et al., 2003a). Extensive hydrophyte stands are also not characteristic of many South African reservoirs, the lake beds of which mostly lie below the trophogenic zone, and/or because seasonal water-level drawn-downs strand hydrophytes and/or desiccate suitable habitat for them.

On various grounds, the prospects of successful biomanipulation in South African reservoirs have already been questioned and seriously challenged (Hart, 2006b); the problem autotrophs that increase radically with nutrient enrichment are dominated by taxa such as Microcystis (Van Ginkel et al., 2000, 2006) and, increasingly, Ceratium (Van Ginkel et al., 2001; Hart and Wragg, 2009), which are too large for direct consumption by grazing zooplankton. In addition, zooplankton populations are not subjected to significant fish predation, since obligate zooplanktivorous fish are absent and young-of-year (YOY) facultative zooplanktivores are numerically, temporally and/or spatially restricted in South African reservoirs (Hart 2006b).

Here, a conceptual model of causal changes in $\mathrm{ZB} / \mathrm{PB}$, using chlorophyll $(\mathrm{Chl})$ as a proxy for $\mathrm{PB}$, is offered. Values of $\mathrm{ZB} / \mathrm{Chl}$ are collated for the first time for a number of South African reservoirs, systems for which empirical evidence regarding fish abundance and composition is severely limited. These data show that $\mathrm{ZB} / \mathrm{Chl}$ ratios decline with rising chlorophyll within most individual reservoirs, a trend that is partly attributable to the negative effect of declining food quality on ZB within systems. Conversely, however, the data also reveal that median (or mean) $\mathrm{ZB} / \mathrm{Chl}$ ratios for individual systems actually rise with trophic status. In this paper, possible causes for these observations are considered and discussed, along with the implications of these for prospective 'corrective' top-down biomanipulation, especially within the eutrophic reservoirs.

\section{Conceptual background to the ZB/PB ratio, and inferences regarding its causal control}

Fundamentally, and all else being equal, 'grazing' zooplankton biomass $(\mathrm{ZB})$ is expected to rise commensurately with the increase of phytoplankton biomass (PB) associated with nutrient (especially P) enrichment (Fig. 1a). Using total chlorophyll (Chl) as a proxy for $\mathrm{PB}$, the $\mathrm{ZB} / \mathrm{Chl}$ ratio should effectively standardise this food effect, and remain constant in relation to trophic status/food resource level (Fig. 1b) (disregarding food-saturation limitations (Gulati, 1990b)). Alternatively, however, this latter 'equilibrium' pattern can decrease (Fig. 1c) or increase (Fig. 1d). Empirical declines in this ratio with rising food levels (Fig. 1c) have been commonly observed, and attributed to rising predation of zooplankton (Fig. 1e) by known increases in zooplanktivorous fishes with rising nutrient status (e.g. Jeppesen et al., 2003a). Such reductions in ZB/PB associated with rising fish predation were especially evident in shallow lakes across a temperate-arctic latitudinal range (Fig. 3 in Jeppesen et al., 2003a), where the ZB/PB dry weight ratio declined from 0.35 (equivalent $\mathrm{ZB} / \mathrm{Chl}=\sim 23.45$ ) in the most oligotrophic lakes to below roughly $0.15(\mathrm{ZB} / \mathrm{Chl}=\sim 10.05)$ in the most eutrophic of 466 study lakes.

Equally logically, however, reductions in zooplankton feeding ability related to adverse changes in food type/quality with rising trophic status (Fig. 1f) can result in a similar inverse relationship, regardless of fish predation. Such reduction in food quality is a well-known outcome of eutrophication (e.g. Sommer et al., 1986; Gulati, 1990b; Moss, 1998b; Wetzel, 2001; Kalff, 2002; Lampert and Sommer, 2007); edible, palatable and nutritionally adequate phytoplankton are increasingly replaced by large colonial and other nutritionally deficient cyanoplankton (see Hart and Bychek (2011) for a contemporary synoptic overview of these nutritional deficiencies). In addition, these large particles depress feeding rates of large cladocerans in particular (Lampert, 1987), potentially reducing ZB and thus the $\mathrm{ZB} / \mathrm{PB}$ ratio, regardless of any predatory impacts of zooplanktivorous fish (Fig. 1e). Since the depressive impacts of the cyanophytic autotrophs that increasingly predominate with rising trophic status are strongest on the large-bodied daphniid zooplankton (Gliwicz and Siedlar, 1980; Lampert, 1987; Gliwicz, 1990) that exert highest grazing pressures (Lampert, 1987), a decline in food quality can lead to disproportionately 


\begin{tabular}{|c|c|c|c|c|c|c|}
\hline \multicolumn{7}{|c|}{$\begin{array}{l}\text { Table } 1 \\
\text { Best-fit linear }(\mathrm{Y}=a+b \mathrm{X}) \text { or power }\left(\mathrm{Y}=a \mathrm{X}^{b}\right) \text { regression statistics for zooplankton biomass }(\mathrm{ZB}) \text { as } \\
\text { functions of concurrent chlorophyll levels }(\mathrm{Chl}) \text { in South African reservoirs. Suffixes for each system } \\
\text { identify whether the best-fit regression is linear }(-\mathrm{L}) \text { or power }(-\mathrm{P}) \text {. Data sources are listed in Table } 2 \text {. }\end{array}$} \\
\hline \multirow[t]{2}{*}{ Dam system } & \multicolumn{5}{|c|}{ Regression statistics } & \multirow[t]{2}{*}{ Notes } \\
\hline & $a$ & $b$ & $r^{2}$ & $n$ & $P$ & \\
\hline \multicolumn{7}{|c|}{ Clear water (Oligo/mesotrophic) systems } \\
\hline Midmar - L & 21.1 & 4.22 & 0.120 & 195 & $* * *$ & \\
\hline Albert Falls - P & 30.5 & 0.26 & 0.093 & 195 & $* *$ & \\
\hline Nagle $-\mathrm{L}$ & 9.3 & 12.92 & 0.373 & 14 & $*$ & \\
\hline Inanda $-\mathrm{P}$ & 93.7 & -0.59 & 0.192 & 13 & ns & \\
\hline \multicolumn{7}{|c|}{ Biogenically turbid (eutrophic) systems } \\
\hline Hartbeespoort $-\mathrm{P}$ & 288.3 & -0.08 & 0.010 & 133 & ns & Jarvis, 1987 (Figs 2.0A \& 2.2D) \\
\hline Roodeplaat $-\mathrm{P}$ & 367.1 & -0.17 & 0.026 & 86 & ns & \\
\hline Rietvlei - L & 286.4 & 6.40 & 0.561 & 8 & $*$ & Not all readings concurrent \\
\hline \multicolumn{7}{|c|}{ Minerally turbid systems } \\
\hline Vanderkloof $-\mathrm{P}$ & 182.3 & 0.31 & 0.127 & 7 & ns & Annual means-open lake \\
\hline Vanderkloof - P & 5.9 & 1.15 & 0.381 & 86 & $* * *$ & Shallow embayment \\
\hline Spioenkop - L & -0.7 & 4.22 & 0.251 & 9 & ns & \\
\hline Wagendrift $-\mathrm{L}$ & -13.6 & 10.05 & 0.637 & 10 & $* *$ & \\
\hline
\end{tabular}

rapid decreases in $\mathrm{ZB}$, and thus in $\mathrm{ZB} / \mathrm{Chl}$ ratios.

Alternatively, the $\mathrm{ZB} / \mathrm{PB}$ ratio could theoretically rise with trophic status (Fig. 1d), an increase plausibly attributable to one or more of three causes: declining fish predation (Fig. 1e), increasing food quality (Fig. 1f), and, most likely, increases in autochthonous and/or allochthonous detritus particles, and/or non-autotrophic food particles, as trophic status rises.

\section{Materials and methods}

\section{General}

A comparative evaluation was made of zooplankton-chlorophyll $(\mathrm{ZB} / \mathrm{Chl})$ ratios in South African reservoirs for which appropriate data exist. Information was extracted from the author's own original raw data used in various publications, and from other sources (see Table 2). In the absence of original raw data for systems independently studied by other authors, their published figures were photo-enlarged to allow measurements of values of interest with a digital micrometer read to $0.1 \mathrm{~mm}$. All data for Hartbeespoort Dam were derived from plots of 3-point moving mean values of weekly measurements over 6 years (Jarvis, 1987). These smoothed estimates obviously obscure some intrinsic temporal variability, and are not precise concurrent estimates. However, the error associated with this approach is unlikely to negate the general underlying trends described. Sampling frequency varied from weekly (Hartbeespoort), to fortnightly (Midmar, Albert Falls) with monthly sampling for all other systems apart from Rietvlei, where sampling mostly varied between 4 and 6 weeks

The median, rather than the mean, was selected as a measure of central tendency, principally to offset the effect of outlying high and low values within the data. However, some average values are explicitly given (Table 3 ) and used (Fig. 7b) to emphasise one point. General procedures used to obtain original information are outlined below.

\section{Zooplankton biomass (ZB)}

Zooplankton was collected in vertical hauls through the entire water column, or the upper $15 \mathrm{~m}$ thereof. Nets with mesh apertures of between 63 and $160 \mu \mathrm{m}$ were used in different studies, and samples were preserved with formalin for subsequent microscopic enumeration. Resulting (species- or genus-specific) counts of copepod instars were converted to biomass using uniform instar biomass coefficients (see original publications, as noted in Table 2), while cladoceran counts were converted to biomass using published (e.g. Bottrell et al., 1976) or original length-weight regressions (Hart, unpublished data) applied to sample mean lengths (geometric means where available). For Hartbeespoort and Roodeplaat Dams, fresh sample wet weights (WW) were determined. Dry weight (DW) was estimated as one-sixth of fresh weight for Hartbeespoort Dam (NIWR, 1985); for consistency, a similar conversion was made for the WW values reported for Roodeplaat Dam by Van Ginkel (1987).

All resulting biomass estimates $\left(\mathrm{mg} / \mathrm{m}^{2}\right)$ are reported as water column integrated volumetric values as $\mathrm{mg} / \mathrm{m}^{3}(\mu \mathrm{g} / \ell)$ DW, using corrections based on site- and date-specific records of net haul length, or from graphical plots given in these units by the original authors.

\section{Phytoplankton biomass (PB)}

Direct determinations of PB as dry weight are not available concurrently with ZB values for any of the study dams. Accordingly, total chlorophyll $(\mathrm{Chl}, \mu \mathrm{g} / \ell)$ was used as a surrogate measure, with values generally determined from integral hose-pipe samples through the upper 3 or $5 \mathrm{~m}$ of the water column. Chlorophyll has been multiplied by 67 to estimate PB (as $\mu \mathrm{g} / \ell$ dry weight) (Jeppesen et al., 2003a). This approach can progressively underestimate $\mathrm{PB}$ as chlorophyll rises between 1 and $150 \mu \mathrm{g} / \ell$ chlorophyll $a$, since chlorophyll declines from approximately $0.7 \%$ to merely $0.15 \%$ of phytoplankton wet weight (Kasprzak et al., 2008), largely as cyanophytes with inherently more chlorophyll per unit weight than eukaryotic autotrophs predominate at high chlorophyll levels. To avoid this confounding prospect, chlorophyll was used as a direct proxy for PB. Obviously, not all chlorophyll reflects edible food species, and it disregards non-autotrophic foods. However, it is inferred here as a direct measure of food supply (as used for other published PB values determined from chlorophyll - e.g., Jeppesen et al. (2003a)). 


\begin{tabular}{|c|c|c|c|c|c|c|c|c|c|c|}
\hline \multicolumn{11}{|c|}{$\begin{array}{l}\text { Table } 2 \\
\text { The biomass ratio of zooplankton (ZB) to chlorophyll (ChI) (as a surrogate of phytoplankton biomass) in various } \\
\text { South African reservoirs. Ratios for all reservoirs are based on ZB estimates of dry weight per unit volume. }\end{array}$} \\
\hline \multirow{2}{*}{$\begin{array}{l}\text { Reservoir } \\
\text { system } \\
\text { (dam) }\end{array}$} & \multicolumn{2}{|c|}{$\begin{array}{c}\text { Sampling } \\
\text { information }\end{array}$} & \multirow{2}{*}{$\begin{array}{l}\text { Haul } \\
\text { depth } \\
\text { range } \\
\text { (m) }\end{array}$} & \multicolumn{2}{|c|}{$\mathrm{ZB} / \mathrm{Chl}$ ratio } & \multicolumn{2}{|c|}{ Chlorophyll $(\mu \mathrm{g} / \ell)$} & \multicolumn{2}{|c|}{$\begin{array}{c}\text { Zooplankton } \\
\text { biomass } \\
\text { ( } \mu \text { g/l dry weight) }\end{array}$} & \multirow[b]{2}{*}{ Source } \\
\hline & Dates & $n$ & & Median & Mean & Median & Mean & Median & Mean & \\
\hline \multicolumn{11}{|c|}{ Clear-water (Oligo/meso-trophic) systems } \\
\hline Nagle & \begin{tabular}{|c|} 
Jan $91-$ Sep \\
91
\end{tabular} & 14 & 15 & 13.74 & 23.17 & 1.87 & 2.19 & 33.3 & 37.5 & $\begin{array}{l}\text { Original data } \\
\text { (Hart,1996) }\end{array}$ \\
\hline Inanda & $\begin{array}{l}\text { Aug } 92- \\
\text { Aug } 93\end{array}$ & 13 & 15 & 7.59 & 15.4 & 3.74 & 4.35 & 33.1 & 51.3 & $\begin{array}{l}\text { Original data (Hart, } \\
\text { unpubl. data) }\end{array}$ \\
\hline Midmar & $\begin{array}{l}\text { Aug } 89- \\
\text { Sep } 98\end{array}$ & 195 & $10-21$ & 8.70 & 10.06 & 3.75 & 4.10 & 36.5 & 38.5 & $\begin{array}{l}\text { Original data (Hart, } \\
1992,1996)\end{array}$ \\
\hline Albert Falls & $\begin{array}{l}\text { Aug } 89- \\
\text { Aug } 98\end{array}$ & 195 & $5-21$ & 10.05 & 11.84 & 4.38 & 5.83 & 45.7 & 53.7 & $\begin{array}{l}\text { Original data (Hart, } \\
1992,1996)\end{array}$ \\
\hline \multicolumn{11}{|c|}{ Biogenically turbid (eutrophic/hypertrophic) systems } \\
\hline Hartbeespoort & $\begin{array}{l}\text { Jan } 81- \\
\text { Dec } 86\end{array}$ & 132 & $20-30$ & 26.26 & 47.10 & 9.11 & 11.74 & 262.1 & 292.6 & $\begin{array}{l}\text { NIWR (1985); Jarvis } \\
\text { (1987) }\end{array}$ \\
\hline Rietvlei $^{1}$ & \begin{tabular}{|c|} 
Jul $09-$ Jul \\
10
\end{tabular} & 8 & $14-17$ & 27.05 & 36.82 & 12.7 & 30.45 & 439.8 & 607.8 & $\begin{array}{l}\text { Original data (Hart, } \\
\text { unpubl. data; Coetzee, } \\
\text { pers. comm., 2010) }\end{array}$ \\
\hline Roodeplaat $^{2}$ & $\begin{array}{l}\text { Jan } 80- \\
\text { Dec } 81\end{array}$ & 86 & $7-20$ & 12.97 & 88.12 & 26.6 & 31.36 & 248.4 & 392.6 & Van Ginkel (1987) \\
\hline \multicolumn{11}{|c|}{ Minerally turbid systems } \\
\hline Vanderkloof $^{3}$ & $\begin{array}{l}\text { Aug } 81 \text { - } \\
\text { Sep } 83\end{array}$ & 86 & $4-12$ & 6.43 & 14.04 & 1.27 & 2.67 & 13.3 & 26.4 & $\begin{array}{l}\text { Original data (Hart, } \\
\text { 1987) }\end{array}$ \\
\hline Vanderkloof ${ }^{4}$ & $\begin{array}{l}\text { Aug } 77- \\
\text { Jul } 84\end{array}$ & 7 & $70^{5}$ & 6.47 & 9.04 & 1.56 & - & - & - & $\begin{array}{l}\text { Original data (Hart, } \\
1986 \text { ) }\end{array}$ \\
\hline Spioenkop & $\begin{array}{l}\text { Jul } 89- \\
\text { May } 90\end{array}$ & 9 & 15 & 3.22 & 3.82 & 2.61 & 2.68 & 11.5 & 10.7 & $\begin{array}{l}\text { Original data (Hart, } \\
\text { 1999) }\end{array}$ \\
\hline Wagendrift & $\begin{array}{l}\text { Jul } 89- \\
\text { May } 90 \\
\end{array}$ & 10 & $13-15$ & 4.75 & 5.11 & 2.91 & 3.05 & 14.2 & 17.1 & $\begin{array}{l}\text { Original data (Hart, } \\
\text { 2001) }\end{array}$ \\
\hline
\end{tabular}

${ }^{I}$ Ratio is approximation based on median values of chlorophyll and zooplankton collected on separate dates within the same overall annual period. ${ }^{2}$ Data for Stations 1 to 4.

${ }^{3}$ Average haul-depth corrected estimates for 5 sites in a shallow embayment.

${ }^{4}$ Determinations based on weighted annual mean values at a deep $(70 \mathrm{~m})$ off shore site, derived from a total of $n=253$ samples.

${ }^{5}$ Haul counts assumed to derive from $15 \mathrm{~m}$, as zooplankton are concentrated in upper $10 \mathrm{~m}$ (Hart, 1986)

\section{‘Phytoplankton’ edibility}

Using species and cell or colony types and sizes, Jarvis (1987) distinguished between \% biovolumes of 'edible' (Cryptomonas, Chroomonas, Coelastrum, Ankistrodesmus, Cyclotella and nonsheathed Oocystis), 'partly edible' (Aulacoseira, and sheathed Oocystis) and 'largely inedible' (predominantly Microcystis) 'fractions' of total 'phytoplankton' in Hartbeespoort Dam. Here, I partitioned chlorophyll into corresponding edibility classes, simplistically assuming a direct equivalence of chlorophyll and total phytoplankton bio-volume, in order to explore certain features relevant to this account (see 'Results' section).

\section{Zooplankton-phytoplankton ratios (ZB/PB)}

To avoid artefacts in PB associated with changes in proportionate contributions of chlorophyll to mass (see above), the proxy measure of $\mathrm{ZB} / \mathrm{Chl}$ was used. This ratio is qualitatively but not quantitatively comparable to published values of $\mathrm{ZB} / \mathrm{PB}$, but an approximate conversion can be obtained as $\mathrm{ZB} / \mathrm{PB}=\mathrm{ZB} /$ Chl*67 for comparative purposes.

\section{Phosphorus content/trophic status}

As direct values of in situ phosphorus content concurrent with the zooplankton and chlorophyll data reported here are unavailable or inaccessible, chlorophyll is used as a standard general proxy for nutrient content (especially P). This approach is based on the well-established interdependency of these variables, as per classic Vollenweider (1975) and related modelling approaches (e.g. OECD, 1982; Walmsley and Thornton, 1984), despite potential confounding increases of chlorophyll to $\mathrm{P}$ when cyanophyte abundance increases with rising trophic status.

\section{Results}

\section{ZB in relation to chlorophyll level}

Table 1 gives the regression statistics for total $\mathrm{ZB}$ in relation to total chlorophyll (as a proxy measure of food supply). As expected, ZB increases with rising food supply (i.e. Fig. 1a), except in the eutrophic reservoirs in which the change to a negative regression slope (significant or not) is consistent with declining food quality (see below), or rising fish predation (for which no empirical data exist in South African reservoirs). The one system with empirical food quality data (Fig. 2, Hartbeespoort Dam) supports the former 'food quality' explanation. In this system, ZB declines with 'inedible' chlorophyll, in contrast to its increases with 'partly edible' and 'edible' chlorophyll fractions (see further the section on 'ZB and $\mathrm{ZB} / \mathrm{Chl}$ ratios in relation to phytoplankton edibility' below). 


\begin{tabular}{|c|c|c|c|c|c|c|c|c|c|c|}
\hline \multicolumn{11}{|c|}{ 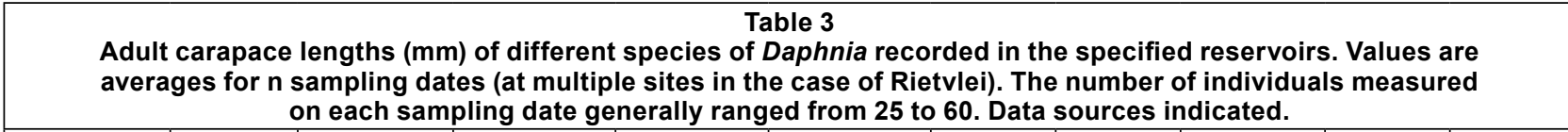 } \\
\hline & 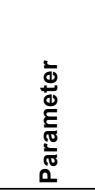 & 离 & 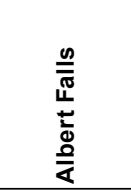 & $\begin{array}{l}\frac{0}{8} \\
\frac{\pi}{2}\end{array}$ & $\begin{array}{l}\frac{\pi}{0} \\
\stackrel{5}{\pi} \\
\stackrel{5}{5}\end{array}$ & 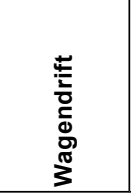 & 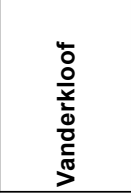 & $\begin{array}{l}\frac{0}{2} \\
\frac{2}{2} \\
\frac{0}{2} \\
\frac{0}{2}\end{array}$ & 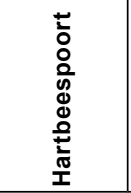 & $\begin{array}{l}\bar{\omega} \\
\frac{\bar{\alpha}}{\bar{\alpha}} \\
\bar{\alpha}\end{array}$ \\
\hline \multirow{3}{*}{ D. gibba } & Mean & - & - & - & - & - & 2.94 & $\mathrm{X}$ & - & - \\
\hline & Range & & & & & & $2.31-3.90$ & & & \\
\hline & $\mathrm{n}$ & & & & & & 191 & & & \\
\hline \multirow{3}{*}{ D. pulex } & Mean & 2.17 & 1.92 & 1.98 & $X$ & $\mathrm{X}$ & - & 1.95 & $\mathrm{X}$ & \\
\hline & Range & $1.38-2.84$ & $1.04-2.60$ & $1.80-2.30$ & & & & $1.63-2.28$ & & \\
\hline & $\mathrm{n}$ & 205 & 195 & 14 & & & & 6 & & \\
\hline \multirow{3}{*}{$\begin{array}{l}D . \\
\text { longispina }\end{array}$} & Mean & 1.45 & 1.38 & 1.41 & 1.27 & $\bar{X}$ & & & $\bar{X}$ & \\
\hline & Range & $1.19-1.94$ & $0.93-1.89$ & $1.26-1.57$ & $1.20-1.56$ & & & & & \\
\hline & $\mathrm{n}$ & 106 & 193 & 14 & 15 & & & & & \\
\hline \multirow{3}{*}{ D. barbata } & Mean & - & - & - & - & - & 1.58 & 1.82 & - & - \\
\hline & Range & & & & & & $1.22-2.20$ & $1.56-1.96$ & & \\
\hline & $\mathrm{n}$ & & & & & & 231 & 5 & & \\
\hline \multirow{3}{*}{ D. laevis } & Mean & $\mathrm{X}$ & $\mathrm{X}$ & 1.65 & 1.62 & - & - & - & - & - \\
\hline & Range & & & $1.52-1.80$ & $1.57-1.80$ & & & & & \\
\hline & $\mathrm{n}$ & & & 7 & 15 & & & & & \\
\hline \multirow{3}{*}{$\begin{array}{l}\text { D. pulex/ } \\
\text { longispina }\end{array}$} & Mean & & & & & 1.69 & & & - & 2.25 \\
\hline & Range & & & & & $1.36-1.94$ & & & up to 2.5 & $1.41-3.21$ \\
\hline & $\mathrm{n}$ & & & & & 9 & & & - & 43 \\
\hline
\end{tabular}

The negative relationship for Inanda Dam (Table 1), although weak, is an interesting exception. Although classed as a 'clear-water' system on account of its low median chlorophyll value in the present data set, it is the most downstream and, correspondingly, enriched system in the Umgeni River reservoir cascade (Midmar, Albert Falls, Nagle and Inanda). Inanda is commonly viewed as functionally eutrophic, exhibiting prominent open-water blooms of Microcystis, generally high chlorophyll values, and extensive rafts of floating hydrophytes (Eichornia and/or Pistia) in its littoral margins.

\section{$\mathrm{ZB} / \mathrm{Chl}$ ratios in relation to within-reservoir chlorophyll levels, and between-system trophic status}

Figure 3 shows estimates of the ZB/Chl ratio within 4 reservoirs of progressively lower trophic status (i.e. declining maximal chlorophyll levels in concurrent data sets). In each reservoir, ZB/Chl declines as chlorophyll increases, contrary to the standardising effect expected of this division procedure (i.e. Fig. 1b). The declines are best described as power regressions, in which the negative exponents decline progressively with declining trophic status (Figs 3a to 3d), with broadly parallel declines in coefficients of determination. In effect, the standardising procedure effectively weakens with rising trophic status, resulting in correspondingly greater declines in $\mathrm{ZB} / \mathrm{Chl}$, (and thus $\mathrm{ZB} / \mathrm{PB}$ ) ratios. Although not illustrated, a comparable inverse trend, best described by negative power regressions, is evident for all other reservoir data sets, apart from Spioenkop, where a positive linear relationship exists. However, it is notable that the maximal $\mathrm{ZB} / \mathrm{Chl}$ values within each system decline markedly as trophic status drops (Fig. 3).

\section{$\mathrm{ZB}$ and $\mathrm{ZB} / \mathrm{Chl}$ ratios in relation to phytoplankton edibility}

Changes in ZB with chlorophyll edibility indicated above (Fig. 2) are also reflected in disparate differences in the rates of decline of the $\mathrm{ZB} / \mathrm{Chl}$ ratio with rising chlorophyll, according

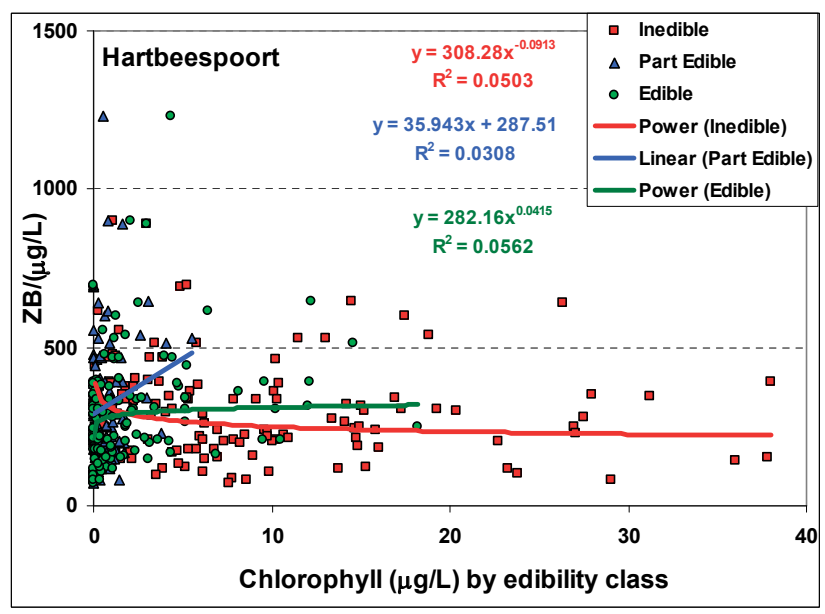

Figure 2

Changes in ZB in Hartbeespoort Dam in relation to concurrent chlorophyll levels differentiated according to edibility classes. Accompanying best fit linear or power regression relationships indicate positive relationships apply except for 'inedible' chlorophyll. Data extracted from Jarvis (1987).

to edibility class (Fig. 4). Although ZB/Chl ratios are high at low chlorophyll levels regardless of edibility, the sharpest decline of the ratio and its predominantly low values at higher chlorophyll levels are both associated with inedible chlorophyll. However, as noted above, the $\mathrm{ZB} / \mathrm{Chl}$ ratio also declines with rising edible and partly edible chlorophyll, invoking a causeeffect dilemma. Are the high $\mathrm{ZB} / \mathrm{Chl}$ ratios at low chlorophyll levels a consequence of chlorophyll reduction by ZB grazing, and/or is zooplankton food-limited? Overall, however, Figs 2 and 4 conform to the hypothesis that declining $\mathrm{ZB}$ is associated with poor food quality, certainly not an unexpected trend. Especially in eutrophic systems, however, the role of detrital food derived from high autotroph abundance adds an unquantifiable confounding effect to this evaluation. 

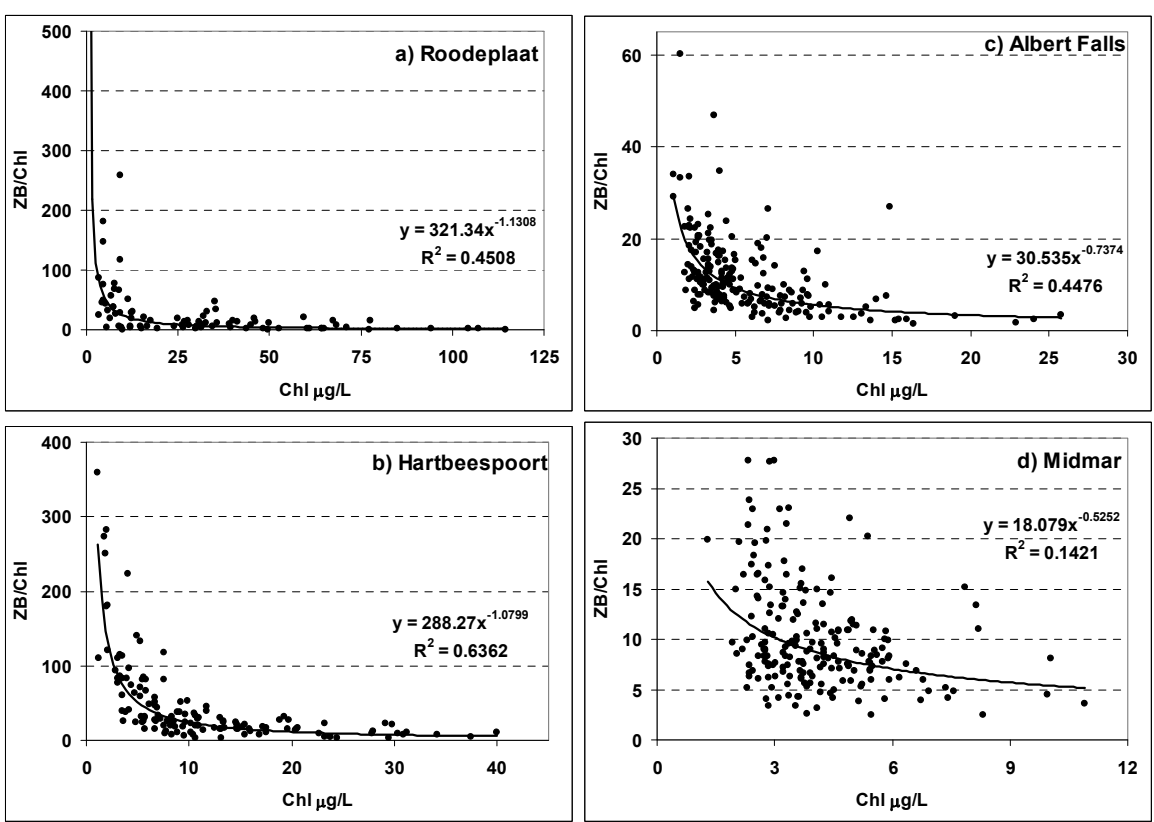

Figure 3

$Z B / C h l$ ratios in relation to concurrent chlorophyll levels within 4 South African reservoirs of declining trophic status (Panels a to d). Note the sequential decline in exponents and most regression coefficients of the power curves fitted for each system. increased, but increased with rising quantities of edible, and especially partly edible chlorophyll (Fig. 6). This trend is consistent with the well-known susceptibility of Daphnia to the disruptive influences of large inedible particles like Microcystis on its feeding ability (Sommer et al., 1986; Jarvis et al., 1987). Microcystis is numerically more prominent in Albert Falls than Midmar (Hart, 2006a), and predominates in Hartbeespoort Dam (NIWR, 1985; Jarvis 1987), while blooms of Ceratium, another large inedible taxon, have also appeared more recently in Hartbeespoort (Van Ginkel et al., 2001) as well as Albert Falls (Hart and Wragg, 2009).

\section{Median ZB/PB ratios between reservoirs of different trophic status}

Median ZB/Chl ratios for the 10 study reservoirs in 3 turbidity and/ or trophic status groupings are

\section{Daphnia biomass in relation to food supply and food type}

Contrasts in relationships between Daphnia biomass and chlorophyll among reservoirs provide further indications for the role of declining food quality as a factor reducing ZB with rising chlorophyll. Figure 5 shows a clear switch from a positive to a negative relationship between Midmar and Albert Falls. Importantly, total zooplankton (and total cladoceran biomass) rose with food supply in both systems (Table 1), with a negative relationship only appearing for total Daphnia biomass (Fig. 5). The same pattern is apparent in Hartbeespoort Dam, in which Daphnia density also declined as inedible chlorophyll

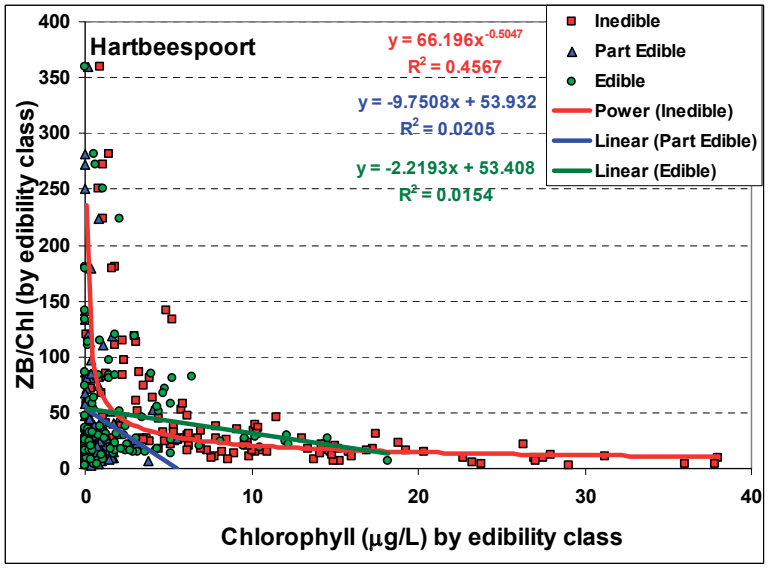

Figure 4

Changes in the $Z B / C h l$ ratio in Hartbeespoort Dam in relation to concurrent chlorophyll levels differentiated according to edibility classes. Best fit linear or power regressions for each chlorophyll class are plotted. Note that the most significant decline is associated with inedible chlorophyll.
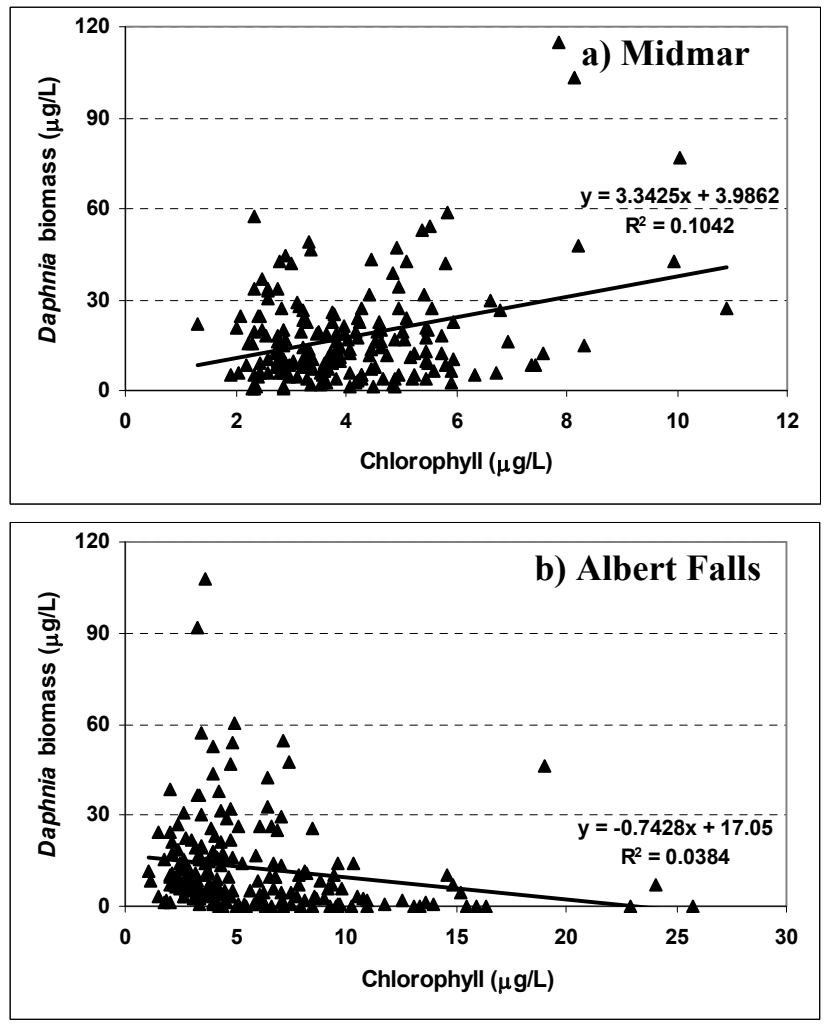

Figure 5

Daphnia biomass in relation to concurrent chlorophyll values in 2 adjacent reservoirs. The inversion from a positive relationship in Midmar to a negative relationship in Albert Falls is attributed to a decline in food quality in the latter, associated with greater quantities of large inedible taxa such as Microcystis. Both regressions are significant: $P<0.001$ for Midmar and $P<0.01$ for Albert Falls. 
given in Table 2. Ratios are arrayed according to median concurrent chlorophyll values within each reservoir class. Apart from Roodeplaat Dam, median values of $\mathrm{ZB} / \mathrm{Chl}$ between individual systems (Fig. 7a) unexpectedly rise (to nearly 30, as median chlorophyll rises to around $15 \mu \mathrm{g} / \ell$ ), rather than declining with chlorophyll as they do within individual systems.

Roodeplaat's position becomes less discordant if average rather than median values are used (Fig. $7 b$ ), but the trend remains the same - an increase in $\mathrm{ZB} / \mathrm{Chl}$ with chlorophyll before an inflection (based on only 1 data point) drops the ratio with further increases in chlorophyll. Importantly, the relationships are described by strongly positive but slightly less significant linear regressions.

This generally positive relationship between average ZB/ $\mathrm{Chl}$ ratios and average ambient chlorophyll levels used to approximate trophic status has important implications regarding the prospective utility of biomanipulation. It also raises the question of how or why ZB increases with trophic status, given the associated general decline in food quality. These points are discussed below.

\section{Discussion}

Converting the median $\mathrm{ZB} / \mathrm{Ch}$ ratios given for South African reservoirs in Table 2 into corresponding $\mathrm{ZB} / \mathrm{PB}$ values indicates that the South African values are broadly comparable with those reported by Jeppesen et al. (2003a) for 466 higher latitude (north temperate to arctic) systems. However, they tend to rise (Fig. 7) from $0.05-0.1$ (i.e. 5-10\%) to $\sim 0.4$ (40\%) across the trophic spectrum, rather than declining from a mean ratio value of $35 \%$ in the most oligotrophic lakes to less than 0 - to $20 \%$ in the most eutrophic lakes in Jeppesen et al.'s (2003a) data set. The decline observed by these authors was attributed to empirically determined rises in fish density and associated predation pressure. Almost all South African values are higher than 2 natural lake values reported by Havens et al. (2009) for the shallow temperate Lago Trasimeno $(\sim 6.5 \%)$ and the cyanophyte-dominated subtropical Lake Apopka ( $1 \%)$. The latter value led the authors to argue that their findings 'support an emerging view that fish predation limits the biomass of crustacean zooplankton in subtropical lakes'. (The ZB/ PB ratios for these 2 lakes are averages 'eye-balled' from their Fig. 2c, and adjusted by $\sim 1.28$ to correct for differences between their $\mathrm{ZB} / \mathrm{PB}$ ratios which are based on carbon (viz. $0.48 * \mathrm{ZB} / 25^{*} \mathrm{Ch}$ lorophyll), using the $\mathrm{Chl}$ : $\mathrm{C}$ ratio proposed by Perga et al. (2006) and Taipale et al. (2008), rather than the dry weight ratios determined here (viz. ZB/67*Chlorophyll)).

Notably, a fundamental difference exists within and between South African reservoirs. Within individual systems, the $\mathrm{ZB} / \mathrm{Chl}$ ratio declines with rising chlorophyll (Fig. 3), whereas, conversely, median (Fig. 7a) or mean (Fig. 7b) ZB/Chl ratios rise with increasing chlorophyll between systems (Fig 7). This contrast merits appraisal.

As the decline in $\mathrm{ZB} / \mathrm{Chl}$ with rising chlorophyll within individual reservoirs occurs regardless of trophic status (Fig. 3), it is difficult to attribute the overall pattern to a declining food quality effect. Rather, the changes may reflect temporal dynamics within individual systems. The high $\mathrm{ZB} / \mathrm{Ch}$ ratios at low chlorophyll plausibly reflect a relatively high ZB grazing on a low standing stock of chlorophyll with a relatively high turnover rate - the classic 'inverted trophic pyramid' characteristic of pelagic systems. They also imply a food-limited zooplankton.

Subsequent declines of the ratio plausibly mirror the approach to a nominally 'standard' predator/prey state within

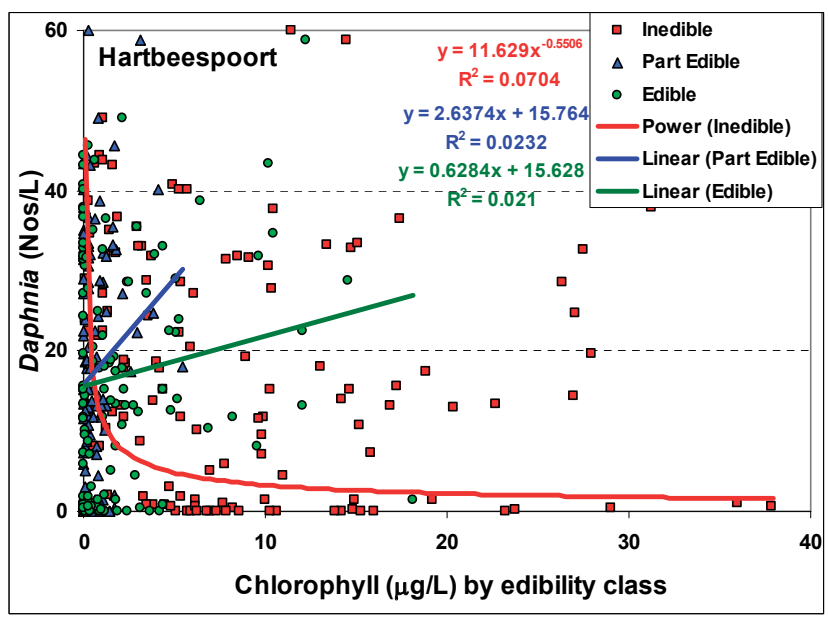

Figure 6

Daphnia density in Hartbeespoort Dam in relation to concurrent levels of chlorophyll of different food quality. Positive

relationships with edible and partly edible foods are replaced by a strong decline with inedible food. The presence/abundance of Daphnia at low levels of inedible food is attributable to the concurrent presence of edible and/or partly edible foods in natural food mixtures.
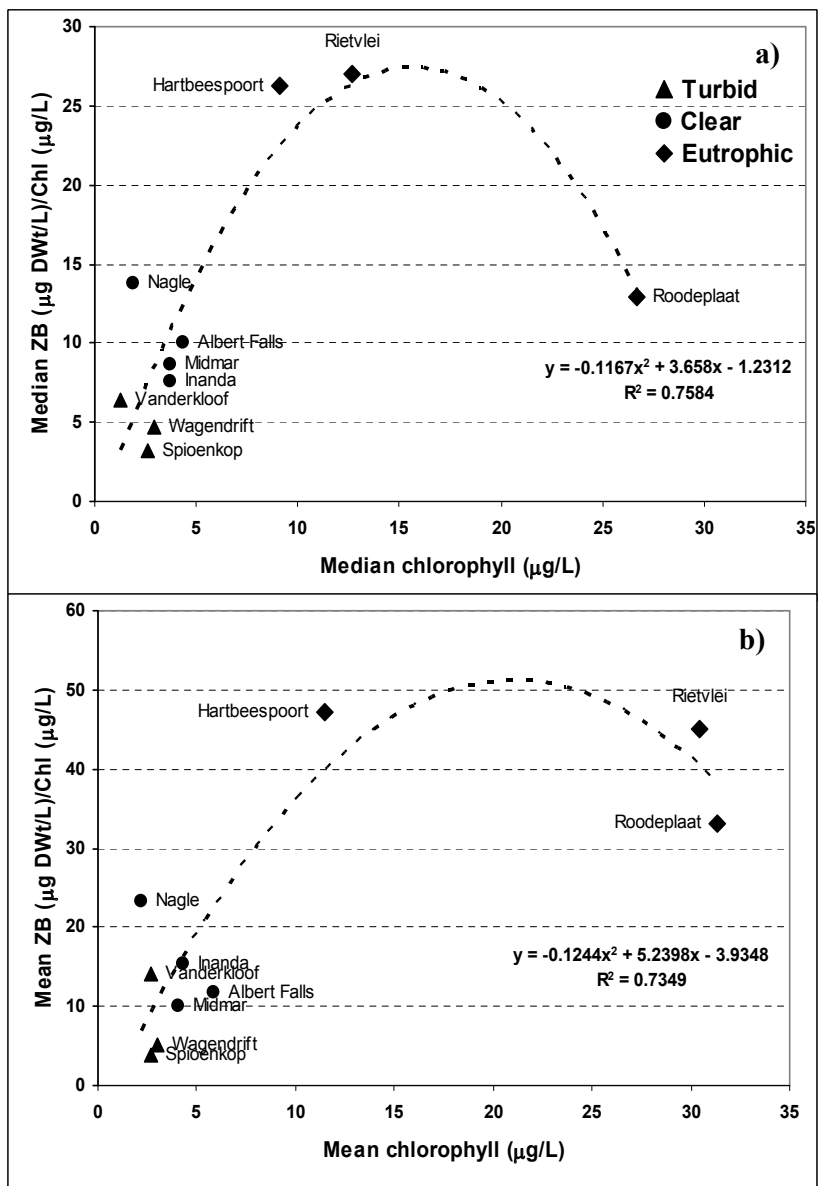

Figure 7

Reservoir-specific a) median and b) average values of ZB/ $\mathrm{Chl}$ values in South African reservoirs of 3 trophic classes in relation to corresponding chlorophyll values. The strong positive relationship for medians is inflected by a single low value for Roodeplaat Dam. The reality of this inflection is discussed in the text. 
the system, with further declines heralding the possible onset of food quality constraints. It is, however, implausible to attribute within-system changes in $\mathrm{ZB} / \mathrm{Chl}$ to increasing fish predation as chlorophyll rises, since life-history constraints of the fish taxa known in the reservoirs will restrict short-term (intra-annual) changes in fish density.

The marked decline in $\mathrm{ZB} / \mathrm{Ch}$ values between eutrophic and oligo-mesotrophic systems (Fig. 3) appears consistent with and attributable to the differences in overall system productivity; eutrophic systems support higher standing stocks - as indicated clearly in the differences in median values of $\mathrm{ZB}$ and chlorophyll between systems of contrasting trophic status (Table 2).

The increase (with one exception) in reservoir-specific ZB/ $\mathrm{Chl}$ ratios with rising productivity (Fig. 7a) raises the question of how ZB is able to increase with trophic status despite the accompanying decline in food quality. Detritus arising from autochthonous production is likely to increase, plausibly augmenting the food supply. Indeed, the importance of bacteria as a food resource for zooplankton, especially in eutrophic waters, was identified by Gliwicz (1969), although empirical evidence from in situ grazing experiments in Hartbeespoort Dam (Hart and Jarvis, 1993) indicated that bacteria accounted for barely $3 \%$ of total cladoceran dietary carbon intake, perhaps owing to the notably small size of natural free-living bacteria in this system (Robarts et al., 1986); the value also under-estimates the food value of bacteria in detritus-bacterial aggregates.

The microbial loop generated from autochthonous (and/or allochthonous) detritus adds additional food sources for particular zooplankton. Allochthonous terrestrial energy subsidies of aquatic food webs have been identified as important in small lakes (e.g. Cole et al., 2010). In reservoirs, with disproportionately high catchment areas, and especially point-source organic inputs from wastewater treatment works, such subsidies may assist strongly in the accumulation of $\mathrm{ZB}$ relative to ambient chlorophyll levels, and generate the parallel increases in ZB/ Chl. No explanation can be offered for the deviation shown by Roodeplaat (Fig. 7a). Its outlying nature possibly reflects a systematic difference in sampling methodology. It is the only totally independent data point in the present collation - and the author of this paper was directly or indirectly involved in research on all of the other reservoirs examined herein. Alternatively, it may reflect limited habitat suitable for zooplankton occupancy, owing to the extent of seasonal hypolimnetic anoxia in this system, for which Van Ginkel (1987) proposed 'space' as the major constraint on zooplankton. However, similar space constraints apply in Hartbeespoort Dam where anoxic hypolimnia occur extensively (NIWR, 1985).

To date, zooplanktivory has been examined in only 2 comprehensive ecosystem studies of South African reservoirs Vanderkloof (Tomasson, 1983) and Hartbeespoort (NIWR, 1985; Cochrane, 1985). In both these systems, overall fish predation on zooplankton was recorded as low or negligible. In line with this, the increases in $\mathrm{ZB} / \mathrm{Chl}$ with rising productivity strongly counter prospects that fish predation on zooplankton becomes more significant as system productivity rises. This inference is empirically supported by the invariably large sizes of Daphnia spp. present in the reservoirs (Table 3). Such large daphniids (and other zooplankton components in some systems) strongly contraindicate the existence of strong, sustained visual zooplanktivory (Hrbáčeck and Hrbáčková-Esslová, 1960; Brooks and Dodson, 1965; Hart and Bychek, 2011), commonly evident in warm subtropical lakes (Jeppesen et al., 2007). Overall, biomanipulationinduced reductions in zooplanktivory are unlikely to manifest in major improvements in grazer control of large planktonic algae and/or cyanophytes that dominate the eutrophic and hypertrophic South African reservoirs, the inedibility and suppressive influence of which on daphniids in particular is ubiquitously acknowledged by all authorities.

Prospects for biomanipulation paradoxically appear theoretically or practically better in Australian reservoirs, in which zooplanktivorous fishes enigmatically appear important (Matveev et al., 2002; Hunt et al., 2003; Matveev, 2003; Sierp et al., 2009), in contrast to South African systems that are otherwise limnologically similar.

In natural lakes, planktivorous fish generally impact significantly on zooplankton, as observed in many cooler temperate lakes around the world (Jeppesen et al., 1997, 2003a; Vakkilainen et al., 2004), and the $\mathrm{ZB} / \mathrm{PB}$ ratio commonly declines with rising trophic status (e.g. Jeppesen et al., 2003a). As fish stocks rise concurrently (e.g. Jeppesen et al., 2003a, 2005, 2007; Havens et al., 2009), the decline in $\mathrm{ZB} / \mathrm{PB}$ ratio is plausibly attributable to rising top-down controls of fish on zooplankton; thus prospects of ameliorating the consequences of eutrophication by top-down biomanipulation - reducing zooplanktivorous fish - appear more promising.

Conversely, however, Vanni et al. (2006) effectively ascribe the reduction in $\mathrm{ZB} / \mathrm{PB}$ to increases in $\mathrm{PB}$ in response to nutrient recycled by fish rather than $\mathrm{ZB}$ depletion by fish; in other words, a bottom-up rather than top-down effect. Their argument suggests that the most likely positive benefits of fish manipulation in eutrophic South African reservoirs are likely to derive from bottom-up rather than top-down effects of fish assemblage modifications. This would involve removal of overabundant 'coarse' fish species - particularly exotic common carp (Cyprinus carpio) whose bioturbation effects undoubtedly sustain strong internal nutrient loadings, along with indigenous catfish (Clarias gariepi$n u s$ ) that both dominate the ichthyomass in the eutrophic reservoirs studied (Harding et al., 2009).

\section{Conclusions}

In individual South African reservoirs, ZB/Chl ratios decline with rising ambient chlorophyll levels, regardless of trophic status. Conversely, disregarding Roodeplaat Dam, median (or mean) values of the $\mathrm{ZB} / \mathrm{Chl}$ ratio for each separate system increase with rising median (or mean) chlorophyll levels, indicating a progressive increase of $\mathrm{ZB} / \mathrm{Chl}$ with system trophic status.

Although evidence regarding fish abundance in reservoirs is severely limited, the increase in $\mathrm{ZB} / \mathrm{Chl}$ ratios with rising trophic status between reservoirs implies that fish predation on zooplankton has little or no significant impact on $\mathrm{ZB}$, and any such effect certainly does not increase progressively with trophic status. Accordingly, food web modifications to reduce fish predation on zooplankton will be futile to moderate/correct the consequences of eutrophication. In-lake management options other than top-down biomanipulation will be required to reduce the symptoms of eutrophication until such time as its root cause - excessive external nutrient loading - can be effectively controlled. Much greater attention to fish-zooplankton-phytoplankton interactions in reservoirs is also required to provide a secure platform for sustainable (and multi-purpose) management of South African river reservoirs.

\section{Acknowledgments}

Eric Jeppesen, a champion of biomanipulation, introduced me to the $\mathrm{ZB} / \mathrm{PB}$ ratio concept and suggested the merits of its investigation in South African reservoirs as a prelude to their 
prospective top-down biomanipulation. This paper is an auxiliary output of the ongoing Water Research Commission Project No K5/1918 'Foodweb interactions in South African reservoirs, tracked using stable isotopes' logistically supported by Tshwane Water and Nature Conservation authorities. I thank Bill Harding for including me in this (his) project. His open-minded receptiveness to my reservations regarding biomanipulation prospects for South African reservoirs in general is appreciated. The former Inland Water Ecosystems section of what is now the South African National Research Foundation (NRF) and the Research Office of the University of Natal/KwaZulu-Natal supported my original earlier studies which have been drawn upon extensively in compiling this account. However, the views expressed herein do not necessarily reflect those of the NRF.

This account arises from part of plenary address 'Plankton, fish and man: biotic structures and functional interactions in water quality management of South African Man-Made Lakes' at the $31^{\text {st }}$ conference of the International Society of Limnology in Cape Town, August 2010.

I greatly appreciate the detailed and critically insightful reviewer's comments of Dr Ramesh D Gulati, which were of particular help in improving the content and structure of this manuscript.

\section{References}

ALLANSON BR, HART RC, O'KEEFFE JH and ROBARTS RD (1990) Inland Waters of Southern Africa. An Ecological Perspective. Kluwer Academic Publishers, Dordrecht.

BOTTRELL HH, DUNCAN A, GLIWICZ ZM, GRYGIEREK E, HERZIG A, ILLBRICH-ILKOWSKA A, KURASAWA H, LARSSON P and WEGLENSKA T (1976) A review of some problems in zooplankton production studies. Norw. J. Zool. 24 419-56.

BROOKS JL and DODSON SI (1965) Predation, body size, and composition of plankton. Science 150 28-35.

COCHRANE KL (1985) The population dynamics and sustainable yield of the major fish species in Hartbeespoort Dam. Ph.D. Thesis, University of the Witwatersrand, Johannesburg.

COETZEE L (2010) Personal communication with Ms Leanne Z Coetzee, 4 Oct 2010, Scientific Services, Tshwane Water, Pretoria. COLE JC, CARPENTER SR, KITCHELL J, PACE ML, SOLOMON CT and WEIDEL B (2010) Strong evidence for terrestrial support of zooplankton in small lakes based on stable isotopes of carbon, nitrogen, and hydrogen. Proc. Nat. Acad. Sciences doi:/10.1073/ pnas1012807108. 6 pp.

DWAF (SOUTH AFRICAN DEPARTMENT OF WATER AFFAIRS AND FORESTRY) (2004) National Water Resource Strategy ( $1^{\text {st }}$ edn.) Department of Water Affairs and Forestry, Pretoria.

DWA (SOUTH AFRICAN DEPARTMENT OF WATER AFFAIRS) (2009) Green Drop Report. South African Waste Water Quality Management Performance. Department of Water Affairs, Pretoria, South Africa.

GLIWICZ ZM (1969) The share of algae, bacteria and trypton in the food of the pelagic zooplankton of lakes with various trophic characteristics. Bull. Acad. Pol. Sci. 17 159-165.

GLIWICZ ZM (1990) Why do cladocerans fail to control algal blooms? Hydrobiol. 200/201 83-97.

GLIWICZ ZM (2005) Food web interactions: why are they reluctant to be manipulated? Verh. Int. Verein. Limnol. 29 73-88.

GLIWICZ ZM and SIEDLAR E (1980) Food size limitation and algae interfering with food collection in Daphnia. Arch. Hydrobiol. 88 $155-177$.

GRAHAM JL (2007) Harmful algal blooms. U.S. Department of the Interior. U.S. Geological Survey. Fact Sheet 2006-3147. 2 pp.

GULATI RD (1990a) Zooplankton structure in the Loosdrecht lakes in relation to trophic status and recent restoration measures. Hydrobiol. 191 173-188.
GULATI RD (1990b) Structural and grazing responses of zooplankton community to biomanipulation of some Dutch water bodies. Hydrobiol. 200/201 99-118.

GULATI RD, LAMMENS EHRR, MEIJER M-L and VAN DONK E (eds.) (1990) Biomanipulation, tool for water management. Hydrobiol. 200/201. 1-628.

GULATI RD and VAN DONK E (2002) Lakes in the Netherlands, their origin, eutrophication and restoration: state-of-the-art review. Hydrobiol. 478 73-106.

GULATI RD, PIRES LMD and VAN DONK E (2008) Lake restoration studies: failures, bottlenecks and prospects of new echotechnological measures. Limnologica 38 233-247.

HANSSON L-A, ANNADOTTER H, BERGMAN E, HAMRIN SF, JEPPESEN E, KAIRESALO T, LUOKKANEN E, NILSSON P-A, SØNDERGAARD M and STRAND J (1998) Biomanipulation as an application of food-chain theory: constraints, synthesis, and recommendations for temperate lakes. Ecosystems 1 558-574.

HARDING WR (2008) The determination of annual phosphorus loading limits for South African dams. WRC Report No. 1687/1/08. Water Research Commission, Pretoria. 68 pp.

HARDING WR, DOWNING TG, VAN GINKEL CE and MOOLMAN PM (2009) An overview of cyanobacterial research and management in South Africa post-2000. Water SA 35 479-484.

HART RC (1986) Zooplankton abundance, community structure and dynamics in relation to inorganic turbidity, and their implications for a potential fishery in subtropical Lake le Roux, South Africa. Freshwater Biol. 16 351-371.

HART RC (1987) Population dynamics and production of five crustacean zooplankters in a subtropical reservoir during years of contrasting turbidity. Freshwater Biol. 18 287-318.

HART RC (1992) Aspects of comparative plankton ecology in cascading Mgeni River reservoirs (Midmar, Albert Falls, and Nagle): an overview. S. Afr. J. Aquat. Sci. 18 20-41.

HART RC (1996) Comparative ecology of plankton in cascading warm-water reservoirs: aspects of relevance to tropical limnology. In: F Schiemer F and Boland KT (eds.) Perspectives in Tropical Limnology. SPB Academic Publishing bv, Amsterdam. 113-130.

HART RC (1999) On the limnology of Spioenkop, a turbid reservoir on the upper Thukela River, with particular reference to the structure and dynamics of its community. Water SA 25 519-528.

HART RC (2001) A baseline limnological study of Wagendrift Dam (Thukela basin, KwaZulu-Natal). Water SA 27 507-516.

HART RC (2006a) Phytoplankton dynamics and periodicity in two cascading warm-water reservoirs from 1989 to 1997 - taxonomic and functional (C-S-R) patterns, and determining factors. Water $S A$ 32 81-92.

HART RC (2006b) Food web (bio)manipulation of South African reservoirs - viable eutrophication management prospect or illusory pipe dream? A reflective commentary and position paper. Water $S A$ 32 567-575.

HART RC and JARVIS AC (1993) In situ determinations of bacterial selectivity and filtration rates by five cladoceran zooplankters in a hypertrophic subtropical reservoir. J. Plankton Res. 15 295-315.

HART RC and WRAGG PD (2009) Recent blooms of the dinoflagellate Ceratium in Albert Falls Dam (KZN): History, causes, spatial features and impacts on a reservoir ecosystem and its zooplankton. Water SA 35 455-468.

HART RC and BYCHEK EA (2011) Body size in freshwater planktonic crustaceans: an overview of extrinsic determinants and modifying influences of biotic interactions. Hydrobiol. 668 61-108.

HAVENS KE, ELIA AC, TATICCHI MI and FULTON RS (2009) Zooplankton-phytoplankton relationships in shallow subtropical versus temperate lakes Apopka (Florida, USA) and Trasimeno (Umbria, Italy). Hydrobiol. 628 165-175.

HOLDREN C, JONES W and TAGGART J (2001) Managing Lakes and Reservoirs. North American Lake Management Society and Terrene Institute, in cooperation with Office of Water Assessment and Watershed Protection Division, United States Environmental Protection Agency, Madison, WI. 383 pp.

HRBÁČECK J and HRBÁČKOVÁ-ESSLOVÁ M (1960) Fish stock as a protective agent in the occurrence of slow-developing dwarf 
species and strains of the genus Daphnia. Int. Rev. Ges. Hydrobiol. 45 355-358.

HUNT R, MATVEEV V, JONES G and WARBURTON K (2003) Structuring of the cyanobacterial community by pelagic fish in subtropical reservoirs: experimental evidence from Australia. Freshwater Biol. 48 1482-1495.

JARVIS AC (1987) Studies on zooplankton feeding ecology and resource utilization in a sub-tropical hypertrophic impoundment (Hartbeespoort Dam, South Africa). Ph.D. Thesis, Rhodes University, Grahamstown. 158 pp. (excluding tables and figures).

JARVIS AC, HART RC and COMBRINK S (1987) Zooplankton feeding on size fractionated Microcystis colonies and Chlorella in a hypertrophic lake (Hartbeespoort Dam, South Africa): implications to resource utilization and zooplankton succession. J. Plankton Res. 9 1231-1249.

JEPPESEN E, JENSEN JP, SØNDERGAARD M, LAURIDSEN TL, PEDERSEN LJ and JENSEN L (1997) Top-down control in freshwater lakes: the role of nutrients, submerged macrophytes and water depth. Hydrobiol. 342/345 151-164.

JEPPESEN E, JENSEN JP, JENSEN C, FAAFENG B, HESSEN DO, SØNDERGAARD M, LAURIDSEN T, BRETTUM P and CHRISTOFFERSEN K (2003a) The impact of nutrient state and lake depth on top-down control in the pelagic zone of lakes: a study of 466 lakes from the temperate zone to the arctic. Ecosyst. 6 313-325.

JEPPESEN E, SØNDERGAARD M, JENSEN JP and LAURIDSEN TL (2003b) Restoration of eutrophic lakes: a global perspective. In: Kumagai M and Vincent WF (eds.) Freshwater Management Global Versus Local Perspectives. Springer, Tokyo. 135-152.

JEPPESEN E, SØNDERGAARD M, MAZZEO N, MEERHOFF M, BRANCO CC, HUSZAR V and SCASSO F (2005) Lake restoration and biomanipulation in temperate lakes: relevance for subtropical and tropical lakes. In: Reddy MV (ed.) Tropical Eutrophic Lakes: Their Restoration and Management. 341-359.

JEPPESEN EJ, MEERHOFF M, JACOBSEN BA, HANSEN RS, SØNDERGAARD M, JENSEN JP, LAURIDSEN TL, MAZZEO N and BRANCO CWC (2007) Restoration of shallow lakes by nutrient control and biomanipulation - the successful strategy varies with lake size and climate. Hydrobiol. 581 269-285.

KALFF J (2002) Limnology: Inland Water Ecosystems. Prentice Hall, Upper Saddle River, New Jersey.

KASPRZAK P, PADISAK J, KOSCHEL R, KRIENITZ L and GERVAIS F (2008) Chlorophyll $a$ concentration across a trophic gradient of lakes: an estimator of phytoplankton biomass? Limnologica 38 327-338.

KRANTZBERG G, TANIK A, DO CARMO J S A, INDARKO A and EKDAL A (2010) Advances in Water Quality Control. Scientific Research Publishing. 338 pp.

LAMPERT W (1987). Feeding and nutrition in Daphnia. Mem. Ist. Ital. Idrobiol. 45 143-192.

LAMPERT W and SOMMER U (2007) Limnoecology: The Ecology of Lakes and Streams (3 $3^{\text {rd }}$ edn.).

MATVEEV V (2003) Testing predictions of the lake foodweb theory on pelagic communities of Australian reservoirs. Oikos 100 149-161.

MATVEEV V, CLOSS G, LIESCHKE JA and SHIRLEY MJ (2002) Are pelagic fish important in the foodwebs of Australian reservoirs? Verh. Int. Verein. Limnol. 28 1-4.

MOSS B (1998a) Shallow lakes biomanipulation and eutrophication. SCOPE Newsletter 29 1-45.

MOSS B (1998b) Ecology of Fresh Waters: Man and Medium, Past to Future (3rd edn.). Blackwell Scientific Publications, Oxford.

NIWR (NATIONAL INSTITUTE FOR WATER RESEARCH) (1985) The Limnology of Hartbeespoort Dam. South African National Scientific Programmes Report No. 110, $x+269$ pp.

OECD (ORGANIZATION FOR ECONOMIC COOPERATION AND DEVELOPMENT) (1982) Eutrophication of Waters. OECD Publications Office, Paris, France. 154 pp.

OSBORNE PL (2005) Eutrophication of shallow tropical lakes. In: O'Sullivan PE and Reynolds CS (eds.) The Lakes Handbook. Volume 2. 279-299.
PERGA M-E, KAINZ M, MATTHEWS B and MAZUMDER A (2006) Carbon pathways to zooplankton: insights from the combined use of stable isotope and fatty acid biomarkers. Freshwater Biol. 51 2041-2051.

PHILLIPS GL (2005) Eutrophication of shallow temperate lakes. In: O'Sullivan PE and Reynolds CS (eds.) The Lakes Handbook. Volume 2. 261-278.

ROBARTS RD, WICKS RJ AND SEPHTON L-M (1986) Spatial and temporal variations macromolecule labelling with [methyl $-{ }^{3} \mathrm{H}$ ] thymidine in a hypertrophic lake. Appl. Environ. Microbiol. 52 1368-1373.

SCHINDLER DW (2006) Recent advances in the understanding and management of eutrophication Limnol. Oceanogr. 51 356-363.

SIERP MT, QIN JG and RECKNAGEL F (2009) Biomanipulation: a review of biological control measures in eutrophic waters and the potential for Murray cod Maccullochella peelii peelii to promote water quality in temperate Australia. Rev. Fish Biol. Fisheries 19 143-165.

SMITH VH and SCHINDLER DW (2009) Eutrophication science: where do we go from here? Trends Ecol. Evol. 24 201-207.

SOMMER U, GLIWICZ ZM, LAMPERT W and DUNCAN A (1986) The PEG model of seasonal succession of planktonic events in fresh water. Arch. Hydrobiol. 106 433-471.

SØNDERGAARD M and JEPPESEN E (2007) Anthropogenic impacts on lake and stream ecosystems, and approaches to restoration. J. Appl. Ecol.44 1089-1094.

SØNDERGAARD M, JEPPESEN E, LAURIDSEN TL, SKOV C, VAN NES EH, ROIJACKERS R, LAMMENS E and PORTIELJE R (2007) Lake restoration: successes, failures and long-term effects. J. Appl. Ecol. 44 1095-1105.

TAIPALE S, KANKAALA P, TIIROLA M and JONES RI (2008) Whole-lake dissolved inorganic ${ }^{13} \mathrm{C}$ additions reveal seasonal shifts in zooplankton diet. Ecol. 89 463-474.

TOMASSON T (1983) The biology and management considerations of abundant large cyprinids in Lake le Roux, Orange River, South Africa. Ph.D. Thesis, Rhodes University, Grahamstown.

VAKKILAINEN K, KAIRESALO T, HIETALA J, BALAYLA DM, BÁCARES E, VAN DE BUND WJ, VAN DONK E, M. FERNÁNDEZ-ALÁEZ M, M. GYLLSTRÖM, L. HANSSON, MIRACLE, MOSS B, ROMO S, RUEDA J and STEPHEN D (2004) Response of zooplankton to nutrient enrichment and fish in shallow lakes: a pan-European mesocosm experiment. Freshwater Biol. 49 1619-1632.

VAN GINKEL CE (1987) 'n Ondersoek na die Rol van Soöplankton in Roodeplaatdam. Department of Water Affairs, Technical Report TR 127. Department of Water Affairs, South Africa. 120 pp.

VAN GINKEL CE, SILBERBAUER MJ and VERMAAK E (2000) The seasonal and spatial distribution of cyanobacteria in South African surface waters. Verh. Int. Ver. Limnol. 27 871-878.

VAN GINKEL CE, HOHLS BC and VERMAAK E (2001) A Ceratium hirundinella (O.F. Müller) bloom in Hartbeespoort Dam, South Africa. Water SA 27 269-276.

VAN GINKEL CE, SILBERBAUER MJ, DU PLESSIS S and CARELSEN CIC (2006) Monitoring microcystin toxin and chlorophyll in five South African impoundments. Verh. Int. Ver. Limnol. 29 1611-1616.

VANNI MJ, BOWLING AM, DICKMAN EM, HALE RS, HIGGINS KA, HORGAN MJ, KNOLL LB, RENWICK WH and STEIN RA (2006) Nutrient cycling by fish supports relatively more lake primary production as ecosystem productivity increases. Ecol. 87 1696-1709.

VOLLENWEIDER RA (1975) Input-output models with special reference to the phosphorus loading concept in limnology. Schweiz. Z. Hydrol. 37 53-83.

WALMSLEY RD and THORNTON JA (1984) Evaluation of OECDtype phosphorus eutrophication models for predicting the trophic status of southern African man-made lakes. S. Afr. J. Sci. 80 257-259.

WETZEL RG (2001) Limnology: Lake and Reservoir Ecosystems (3rd edn.) Academic Press, New York. 